\title{
Environmental Factors and Vitamin D Status in Polish middle-aged women
}

\section{Czynniki środowiskowe a poziom witaminy D u polskich kobiet w średnim wieku}

\author{
Grzegorz Raszewski ${ }^{1, A-F \oplus}$, Konrad Jamka ${ }^{1, A-B, D \oplus}$, Piotr Adamczuk ${ }^{1, A-B, D \oplus}$ \\ ${ }^{1}$ Zakład Toksykologii i Bezpieczeństwa Żywności, Instytut Medycyny Wsi im. Witolda Chodźki, Lublin, Polska \\ $A$ - Research concept and design, B - Collection and/or assembly of data, C - Data analysis and interpretation, \\ $D$ - Writing the article, $E$ - Critical revision of the article, $F$ - Final approval of article
}

Raszewski G, Jamka K, Adamczuk P. Environmental Factors and Vitamin D Status in Polish middle-aged women. Med Środ. 2019; 22(1-2): 20-23. doi: $10.26444 / \mathrm{ms} / 119716$

\begin{abstract}
Objectives. The aim of this study was to investigate the vitamin $D$ levels in a population of middle-aged of women residing in the south-eastern part of Poland. Environmental factors (age, education, place of residence and BMI) that could affect vitamin D levels in a population of studied women were also examined.

Materials and method. The study was conducted at the Institute of Rural Health in Lublin, Poland, in a study group of women aged 45-65 years from the south-eastern part of the country. Serum lipids were determined using an automatic biochemistry analyzer and levels of 25(OH)D were measured using the 25OHD EIA assay Kits. Significance of the differences in quantitative characteristics was investigated using analysis of Man-Whitney test. Univariate correlations between the levels of $25(\mathrm{OH}) \mathrm{D}$ and variables were analyzed using the nonparametric Spearman test.
\end{abstract}

Results. The average of $25(\mathrm{OH}) \mathrm{D}$ level in the studied participants was $25.7 \pm 14.4 \mathrm{ng} / \mathrm{L}$; more than $59 \%$ of participants had vitamin D deficiency. In particular, the mean $25(\mathrm{OH}) \mathrm{D}$ level in group of women with vitamin D deficiency was 14.7 \pm 6.1 $\mathrm{ng} / \mathrm{L}$. The mean age of the patients was $53.9 \pm 5.2$ years; average age range $-45-65$ years. BMI averaged $26.1 \pm 4.8 \mathrm{~kg} / \mathrm{m}^{2}$. This was a highly educated group with an average of $12.7 \pm 3.6$ years of education, who lived mainly in towns (56.8\%). Studies have shown that vitamin D deficiency in healthy middle-aged Polish women is significantly related to BMI and education. In the general population, no significant relationship was found between environmental factors (age, education, place of residence and $\mathrm{BMI}$ ) and vitamin D levels.

Conclusion. Vitamin D supplementation is recommended for middle-aged women

\section{Key words}

environmental factors, middle-aged women, 25-hydroxyvitamin D

\begin{abstract}
Streszczenie
Cel pracy. Celem pracy było zbadanie poziomu witaminy D w populacji kobiet w średnim wieku zamieszkujących południowo-wschodnią część Polski. Badano również czynniki środowiskowe (wiek, wykształcenie, miejsce zamieszkania i BMI) mogące mieć wpływ na poziom witaminy $D$ w populacji badanych kobiet.
\end{abstract}

Materiał i metody. Badanie zostało przeprowadzone w Instytucie Medycyny Wsi w Lublinie, a grupą badawczą były kobiety w wieku od 45 do 65 lat z południowo-wschodniej części kraju. Lipidy w surowicy określono za pomocą automatycznego analizatora biochemicznego, a poziomy $25(\mathrm{OH}) \mathrm{D}$ zmierzono za pomocą zestawów testowych ElA $25(\mathrm{OH}) \mathrm{D}$ (R\&D Systems Minneapolis, USA). Istotność różnic w charakterystyce ilościowej zbadano za pomocą analizy testu Manna-Whitneya. Korelacje jednowymiarowe między poziomami $25(\mathrm{OH}) \mathrm{D}$ i zmiennymi analizowano za pomocą nieparametrycznego testu Spearmana.

Wyniki. Średni poziom $25(\mathrm{OH}) \mathrm{D}$ u badanych kobiet wynosił $25,7 \pm 14,4 \mathrm{ng} / \mathrm{L}$, przy czym ponad 59\% uczestniczek badania miało niedobór witaminy $\mathrm{D}$. U kobiet z niedoborem witaminy D średni poziom $25(\mathrm{OH}) \mathrm{D}$ wynosił 14,7 $\pm 6,1 \mathrm{ng} / \mathrm{L}$. Średni wiek kobiet wynosił $53,9 \pm 5,2$ roku i mieścił się w przedziale od 45 do 65 lat. BMI wynosiło średnio $26,1 \pm 4,8 \mathrm{~kg} / \mathrm{m}^{2}$. Badane

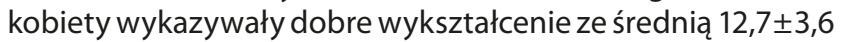
lat edukacji i mieszkały głównie w miastach (56,8\%). Badania wykazały również, że niedobór witaminy D występujący u zdrowych Polek w średnim wieku jest w znacznym stopniu związany z BMI i poziomem wykształcenia. W populacji ogólnej nie stwierdzono istotnego związku pomiędzy czynnikami środowiskowymi (wiek, wykształcenie, miejsce zamieszkania i BMI) a poziomem witaminy $\mathrm{D}$.

Wnioski. Rekomendowana jest suplementacja witaminy D u kobiet w średnim wieku.

\section{Słowa kluczowe}

czynniki środowiskowe, 25-hydroksy-vitamina D, kobiety w średnim wieku

\footnotetext{
Address for correspondence: Grzegorz Raszewski, Zakład Toksykologil i Bezpieczeństwa Żywności, Instytut Medycyny Wsi im. Witolda Chodźki, Polska E-mail: raszewski.grzegorz@imw.lublin.pl
}

\section{INTRODUCTION}

Vvitamin D refers to a group of secosteroid hormones, including cholecalciferol (or vitamin D3) and ergocalciferol (vitamin D2). Vitamin D3 is produced in the skin under the 
influence of ultraviolet radiation (UVB and/or obtained from food, mainly fish. Ergocalciferol is synthesized by plants and fungi, which are the source of vitamin D2 in the diet. Both forms of vitamin $\mathrm{D}$ undergo hydroxylation to 25-hydroxyvitamin D 25(OH)D, calcidiol) in the liver [1], and is the main storage and circulating form of vitamin $\mathrm{D}$ in the human body. Its concentration, as is universally acknowledged, reflects the status of the organism's vitamin D supply. In addition, 1,25-dihydroxy-vitamin $\mathrm{D}(1,25(\mathrm{OH}) 2 \mathrm{D}$, calcidiol), the metabolite formed by hydroxylation of calcidiol, is responsible for the majority of the biological effects of this group of compounds, and the proposed determining factor of its synthesis at tissue level is the serum calcidiol concentration [2].

In numerous scientific reports, hypovitaminosis $\mathrm{D}(25(\mathrm{OH})$ D concentrations lower than $20 \mathrm{ng} / \mathrm{ml}$ have been associated in the pathogenesis of many diseases, including infectious, autoimmune, neoplasmatic, cardiovascular, metabolic and neurological diseases [3]. According to most authors, optimal vitamin D levels are defined as concentrations of $25(\mathrm{OH}) \mathrm{D}$ in serum ranges of $30-80 \mathrm{ng} / \mathrm{ml}$. The concentration range of $20-30 \mathrm{ng} / \mathrm{ml}$ is defined as insufficiency, while levels above $100 \mathrm{ng} / \mathrm{ml}$ are considered a health risk, and greater than $200 \mathrm{ng} / \mathrm{ml}$ - toxic [4].

Hypovitaminosis D is mainly due to insufficient exposure to sunlight as well as insufficient supplementation [5]. The sources of vitamin D in the diet: fish, fish oils, as well as egg yolks, although to a lesser extent. Unfortunately, in Poland the intake of vitamin D from this source is very low [6]. Data concerning the vitamin D status in women in the Polish population are insufficient, particularly in the case of middle-aged women who do not have osteoporosis. These studies are important due to fact that it is well accepted that the middle-aged populations ( $>45$ years of age) are at high risk of vitamin D deficiency [4]. Moreover, some physiological and behavioural factors have been proposed as determinants of serum $25 \mathrm{OH}-\mathrm{D}$ levels. These include, for example: gender, age, race and BMI. Knowledge of these determinants of vitamin $\mathrm{D}$ status is of importance for strategies for the prevention of suboptimal vitamin D status, especially during wintertime [7].

\section{OBJECTIVE}

The aim of this study was to investigate the vitamin D levels in a middle-aged population of women residing in the southeastern part of Poland. According to the obtained data, environmental factors among the middle-aged participants with optimal and insufficiency vitamin $\mathrm{D}$ levels were also studied.

\section{MATERIALS AND METHOD}

Patients. The study was conducted at the Institute of Rural Health in Lublin, Poland, among a study group of women aged over 45 years living in the south-eastern part of the country. Patients were recruited among women who reported to the study facility to undergo a prophylactic densitometric examination. A total of 87 healthy women aged 45-65 were recruited. All participants signed a consent form prior to participation in the study, which was approved by the Ethics Committee at the Institute of Rural Health.

Sample collection, tests and assays. After an overnight fast, blood samples were taken from each patient. Serum samples were separated by centrifugation at $3,000 \mathrm{rpm}$ over a period of 15 minutes, and then stored at $-81^{\circ} \mathrm{C}$ until analysis. The serum cholesterol (TC), HDL-cholesterol (HDL-C) and triglyceride (TG) levels were determined using an automatic biochemistry analyzer (Express Plus, Chiron Diagnostics, USA), with reagents (Siemens Healthcare Diagnostics, Tarrytown, NY, USA), according to the procedure provided by the manufacturer. Serum levels of $25(\mathrm{OH}) \mathrm{D}$ were measured using 25OHD EIA assay Kits (R\&D Systems Minneapolis, USA). Intra- and inter-batch variation coefficients for $25(\mathrm{OH})$ $\mathrm{D}$ were below $10 \%$.

Statisticalanalysis. Data were expressed as the mean \pm standard deviation (SD), according to data distribution. The significance of the differences in quantitative characteristics between groups of 25-hydroxyvitamin D was investigated using analysis of the Man-Whitney test. Univariate correlations between the levels of $25(\mathrm{OH}) \mathrm{D}$ and selected variables were analyzed using the non-parametric Spearman correlation coefficient, according to data distribution. $\mathrm{P}>0.05$ was considered not significant. Statistical analyses were carried out using Graph-Pad Prism-5 for Windows.

\section{RESULTS}

A total of 88 patients recruited by $25(\mathrm{OH})$ status (characteristics shown in Table 1) were finally analyzed in the study; average $25(\mathrm{OH}) \mathrm{D}$ level $-25.7 \pm 14.4 \mathrm{ng} / \mathrm{L}$ More than $59 \%$ of participants had vitamin D deficiency, in particular, the mean $25(\mathrm{OH}) \mathrm{D}$ level in group I with vitamin D deficiency was $14.7 \pm 6.1 \mathrm{ng} / \mathrm{L}$ while in females with group II $(25(\mathrm{OH})$ $\mathrm{D}$ the level $<30 \mathrm{ng} / \mathrm{L}$ was $35.1 \pm 5.1 \mathrm{ng} / \mathrm{L}$. The mean age of the patients was $53.9 \pm 5.2$ years, with an age range of $45-65$ years, and was similar in both groups. In addition, the BMI averaged $26.1 \pm 4.8 \mathrm{~kg} / \mathrm{m}^{2}$. The prevalence of obesity in females with II group was $25 \%$, while in women with vitamin D deficiency $-19.2 \%$, and $7.7 \%$ were underweight. This was a highly educated group with an average of $12.7 \pm 3.6$ years of education, who lived mainly in towns (56.8\%).

The levels of lipids: total cholesterol, HDL cholesterol, LDL cholesterol, and trigliceride were 218.0 \pm 48.6 ; 52.4 \pm 13.7 ; $144.1 \pm 45.1$ and $146.0 \pm 61.2$, respectively. No significant differences were observed in the characteristics between the two groups of studied women.

The relationship between the levels of $25(\mathrm{OH}) \mathrm{D}$ and environmental factors (age, education, environment and $\mathrm{BMI}$ ) in the total population and in the $25(\mathrm{OH}) \mathrm{D}$ groups were analyzed. The results showed that the mean $25(\mathrm{OH}) \mathrm{D}$ serum concentrations in the total population was $25.7 \pm 14.4$ $\mathrm{ng} / \mathrm{ml}$, which was not correlated with tested parameters (Tab. 2 ). However, as shown in the Figures, subgroup analysis showed an inverse relationship between the levels of $25(\mathrm{OH})$ $\mathrm{D}$ and $\mathrm{BMI}$, as well as the education in women with vitamin $\mathrm{D}$ deficiency. 
Table 1. Characteristics of the study population

\begin{tabular}{|c|c|c|c|}
\hline $\begin{array}{l}\text { Prevalence, } \% \\
25 \text {-hydroxyvitamin D }\end{array}$ & & & \\
\hline \multirow[t]{2}{*}{ Characteristics } & Total & $\leq 30 \mathrm{ng} / \mathrm{mL}$ & $>30 \mathrm{ng} / \mathrm{mL}$ \\
\hline & $\mathrm{n}=88$ & $\mathrm{Grl}, \mathrm{n}=52$ & Gr II, $\mathrm{n}=36$ \\
\hline Age, years; Mean (SD) * & $53.9(5.2)$ & $53.5(4.8)$ & $54.5(5.8)$ \\
\hline Education, years; Mean (SD) * & $12.7(3.6)$ & $12.5(3.4)$ & $13.1(3.9)$ \\
\hline 8 years & 20.4 & 15.4 & 27.8 \\
\hline $9-12$ years & 42.0 & 50.0 & 27.8 \\
\hline$>12$ years & 37.6 & 34.6 & 44.4 \\
\hline Body Mass Index, $\mathrm{kg} / \mathrm{m}^{2} ;$ Mean (SD) * & $26.1(4.8)$ & $25.9(5.3)$ & $26.6(4.1)$ \\
\hline$<18.5$ & 4.6 & 7.7 & 0.0 \\
\hline $18.5-25$ & 38.6 & 40.4 & 36.1 \\
\hline $25.0-30$ & 35.2 & 32.7 & 38.9 \\
\hline$>30$ & 21.6 & 19.2 & 25.0 \\
\hline place of residence: Town & 56.8 & 57.7 & 55.5 \\
\hline Little town & 22.7 & 23.1 & 22.2 \\
\hline Village & 20.5 & 19.2 & 22.3 \\
\hline 25-hydroxyvitamin D, ng/mL Mean (SD) & $25.7(14.4)$ & $14.7(6.1)$ & $35.1(5.1)$ \\
\hline \multicolumn{4}{|l|}{ Lipids:(mg/ml); Mean (SD) } \\
\hline Total Cholesterol ${ }^{*}$ & $218.0(48.6)$ & $219.6(45.3)$ & $215.7(53.6)$ \\
\hline HDL-cholesterol * & $52.4(13.7)$ & $50.4(13.2)$ & $55.2(14.0)$ \\
\hline LDL-cholesterol * & $144.1(45.1)$ & $145.7(44.1)$ & $141.9(47.1)$ \\
\hline Triglycerides * & $146.0(61.2)$ & $156.0(66.5)$ & $131.7(50.0)$ \\
\hline
\end{tabular}

*There were no significant differences in age, years of education, body mass index (BMI), lipids levels between the 25 -hydroxyvitamin D groups, using analysis of the Man-Whitney test.

Table 2. Relationship between levels of $25(\mathrm{OH}) \mathrm{D}$ and environmental factors

\begin{tabular}{lccc}
\hline & \multicolumn{3}{c}{ 25-hydroxyvitamin $\mathrm{D}$} \\
\hline \multirow{2}{*}{ Characteristics } & Total; & $\leq 30 \mathrm{ng} / \mathrm{mL} ;$ & $>30 \mathrm{ng} / \mathrm{mL} ;$ \\
& $\mathrm{n}=88$ & $\mathrm{Gr}, \mathrm{n}=52$ & $\mathrm{Gr} I \mathrm{l}, \mathrm{n}=36$ \\
\hline \multirow{2}{*}{ Age, years } & $\mathrm{p}=0.051$ & $\mathrm{p}=0.269$ & $\mathrm{p}=0.106$ \\
& $\mathrm{r}=0.176$ & $\mathrm{r}=0.087$ & $\mathrm{r}=0.213$ \\
\hline \multirow{2}{*}{ Education, years } & $\mathrm{p}=0.132$ & $\mathrm{p}=0.029$ & $\mathrm{p}=0.209$ \\
& $\mathrm{r}=0.120$ & $\mathrm{r}=0.265$ & $\mathrm{r}=-0.139$ \\
\hline \multirow{2}{*}{ Body Mass Index, $\mathrm{kg} / \mathrm{m}^{2}$} & $\mathrm{p}=0.421$ & $\mathrm{p}=0.034$ & $\mathrm{p}=0.387$ \\
& $\mathrm{r}=0.021$ & $\mathrm{r}=-0.256$ & $\mathrm{r}=0.049$ \\
\hline \multirow{2}{*}{ Environment } & $\mathrm{p}=0.140$ & $\mathrm{p}=0.113$ & $\mathrm{p}=0.060$ \\
& $\mathrm{r}=0.116$ & $\mathrm{r}=0.170$ & $\mathrm{r}=0.264$ \\
\hline \multirow{2}{*}{ Total Cholesterol } & $\mathrm{p}=0.401$ & $\mathrm{p}=0.482$ & $\mathrm{p}=0.439$ \\
& $\mathrm{r}=-0.027$ & $\mathrm{r}=-0.006$ & $\mathrm{r}=0.026$ \\
\hline \multirow{2}{*}{ HDL-cholesterol } & $\mathrm{p}=0.155$ & $\mathrm{p}=0.069$ & $\mathrm{p}=0.371$ \\
& $\mathrm{r}=0.110$ & $\mathrm{r}=-0.208$ & $\mathrm{r}=0.057$ \\
\hline \multirow{2}{*}{ LDL-cholesterol } & $\mathrm{p}=0.382$ & $\mathrm{p}=0,290$ & $\mathrm{p}=0.302$ \\
\hline \multirow{2}{*}{ Triglycerides } & $\mathrm{r}=-0,033$ & $\mathrm{r}=0,078$ & $\mathrm{r}=-0.089$ \\
\hline & $\mathrm{p}=0.085$ & $\mathrm{p}=0,196$ & $\mathrm{p}=0.394$ \\
& $\mathrm{r}=-0.147$ & $\mathrm{r}=0,121$ & $\mathrm{r}=-0.046$ \\
\hline
\end{tabular}

\section{DISCUSSION}

As is well known, vitamin D deficiency is the result of inadequate exposure to sunlight and inefficient production in the skin, not enough vitamin $\mathrm{D}$ in the diet, and certain health conditions, e.g. gastrointestinal, hepatic, and renal diseases
[3]. Scientific evidence also indicates that it is common in people worldwide. Similarly, in Poland about $40 \%$ and $60 \%$ of pre- and post-menopausal women have a concentration of 25(OH)D: lower than $20 \mathrm{ng} / \mathrm{ml}$ and $30 \mathrm{ng} / \mathrm{ml}$, respectively [8]. This fact is important in the context of public health because vitamin D deficiency is independently associated with an increased risk of mortality in the general population, and is a particular risk for women, being associated, for example, with a higher risk of bone metabolic diseases [9].

The mean $25(\mathrm{OH}) \mathrm{D}$ serum concentrations in the studied population of women was $25.7 \pm 14.4 \mathrm{ng} / \mathrm{ml}$, which is consistent with the latest research by other authors. In a recent study from 2019, Delle Monache et al. showed that more than $80 \%$ of women presented a serum $25(\mathrm{OH}) \mathrm{D}$ concentration lower than $30 \mathrm{ng} / \mathrm{mL}(75 \mathrm{nM})$, with the majority of values falling between $10-20 \mathrm{ng} / \mathrm{mL}[10]$.

In the current study, only educational level and place of residence are markers of socio-economic status, and the BMI level as a marker of diet and obesity. It is obvious that the diet is due to socio-economic status and social class, as well as education $[11,12]$, which may be linked to vitamin D status. This was not found in the entire population of women. However, a significant interaction was found between BMI levels, educational level and vitamin $\mathrm{D}$, in women with vitamin $\mathrm{D}$ deficiency. Other studies also show that the BMI, together with the intake of alcohol, gender, ethnicity and tobacco use, are associated with the risk of vitamin D deficiency $[10 ; 13]$. There are also studies indicating that among the different clinical characteristics, BMI demonstrated the highest significant inverse correlation with serum $25(\mathrm{OH})$ $\mathrm{D}$ values, independent of season and age [10]. These results also indicate that vitamin $\mathrm{D}$ deficiency is more prevalent in those who are obese. Obesity and BMI levels are associated with lower vitamin D levels, and according to Tønnesen etnd al. and others, obesity is recognized as being associated with vitamin D deficiency as adipose tissue sequesters $25(\mathrm{OH}) \mathrm{D}$, resulting in an inverse relationship between vitamin $\mathrm{D}$ and BMI [12]. This relationship is also shown in the current study.

Education, another significant factor in this study, was also examined and showed its relationship with $25(\mathrm{OH}) \mathrm{D}$ levels in women with vitamin D deficiency. Similar results were obtained by Parva et all. who concluded that better educated people generally have better health awareness, which results in a statistically significantly lower rate of vitamin D deficiency [8].

In conclusion, this study reveals that vitamin $\mathrm{D}$ deficiency is present in healthy middle-aged Polish women, and that vitamin $\mathrm{D}$ deficiency is significantly associated with BMI and level of education.

\section{REFERENCES}

1. Cesari M, Incalzi RA, Zamboni V, Pahor M. Vitamin D hormone: a multitude of actions potentially influencing the physical function decline in older persons. Geriatr Gerontol Int. 2011; 11(2): 133-42.

2. DeLuca H. Overview of general physiologic features and functions of vitamin D. Am J Clin Nutr. 2004;80 Supp 1:1689S-96.

3. Holick MF. Vitamin D deficiency. N Engl J Med. 2007; 357: 266-81.

4. Aleteng Q, Zhao L, Lin H, Xia M, Ma H, Gao J, et al. Optimal Vitamin D Status in a Middle-Aged and Elderly Population Residing in Shanghai, China. Med Sci Monit. 2017; 23: 6001-6011

5. Holick MF, Binkley NC, Bischoff-Ferrari HA. Guidelines for preventing and treating vitamin D deficiency and insufficiency revisited. J Clin Endocrinol Metab. 2012; 97(4): 1153-58 
6. Malesa-Ciećwierz M, Usydus Z. Vitamin D: can fish food-based solutions be used for reduction of vitamin D deficiency in Poland? Nutrition. 2015 Jan; 31(1): 187-92.

7. Parva NR, Tadepalli S, Singh P, Qian A, Joshi R, Kandala H, Nookala VK, Cheriyath P. Prevalence of Vitamin D Deficiency and Associated Risk Factors in the US Population (2011-2012). Cureus. 2018, 5;10(6):e2741.

8. Kołodziejczyk M., Stacherzak-Pawlik J. Stężenie 25-hydroksywitaminy D w surowicy u kobiet w wieku pre- i pomenopauzalnym. Diagn Lab. 2017; 53(2): 85-90.

9. Hutchinson MS, Grimnes G, Joakimsen RM. Low serum 25-hydroxyvitamin D levels are associated with increased all-cause mortality risk in a general population: The Tromso study. Eur J Endocrinol. 2010; 162(5): 935-42.
10. Delle Monache S, Di Fulvio P, Iannetti E, Valerii L, Capone L, Nespoli MG, et al. Body mass index represents a good predictor of vitamin D status in women independently from age. Clin Nutr. 2019; 38(2): 829-834].

11. Darmon N, Drewnowski A. Does social class predict diet quality? Am J Clin Nutr. 2008; 87(5): 1107-17.

12. Tønnesen R, Hovind PH, Jensen LT, Schwarz P. Determinants of vitamin $\mathrm{D}$ status in young adults: influence of lifestyle, sociodemographic and anthropometric factors. BMC Public Health 2016; 11;16:385.

13. Vashi PG, Lammersfeld CA, Braun DP, Gupta D. Serum 25 -hydroxyvitamin $\mathrm{D}$ is inversely associated with body mass index in cancer. Nutr J. 2011;16 (10): 51-65. 